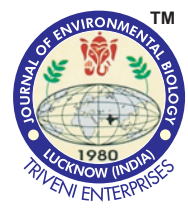

\title{
Synchronicity of climate driven regime shifts among the East Asian marginal sea waters and major fish species
}

\section{Authors Info \\ S.M.M. Rahman', H.K. Jung ${ }^{2}$, H.J. Park', J.M.Park ${ }^{3}$ and C.I. Lee ${ }^{2 *}$ \\ ${ }^{1}$ Research Institute for Dok-do andUlleung-do, Kyungpook National University, Daegu, 41566, Republic of Korea \\ ${ }^{2}$ Departmentof Marine Bioscience, College of Life Science, \\ Gangneung-Wonju National University, Gangneung, 25457, Republic of Korea \\ ${ }^{3}$ Dokdo Research Center, East Sea Research Institute, Korea Institute of Ocean Science \& Technology, Uljin, 36315, Republic of Korea \\ *Corresponding Author Email : leeci@gwnu.ac.kr}

\section{Edited by}

Professor Wong Yu Park

Reviewed by

Dr. Hee Chan Choi

Dr. Dong-Woon Hwang

\section{Abstract}

Aim: Climate regime shift in 1976/77, 1988/89 and 1998 were well detected in different East Asian marginal sea ecosystems. However, information about synchronous pattern of these regime shifts among the ecosystems is limited.

Methodology: In this study, synchronicity of regime shifts among major climate patterns was examined in north Pacific, sea water temperatures, and major fish species in north East/Japan Sea, south East/Japan Sea, East China Sea and Yellow Sea.

Results: Results suggest that 1976/77 climate regime shift was marked for a long duration period (19701979) among climate indices and sea water temperature. Early positive shifts were detected in sea water temperature of East China Sea (1970) and Yellow Sea (1972). Early positive shifts were detected in walleye pollock, Japanese anchovy and hairtail. In 1988/89 CRS, most climate patterns were shifted within very short time (1987-1989). Positive shifts of sea water temperature in East Asian marginal sea were detected within very short time (1985-1989). Japanese sardine (1983) and walleye pollock (1985) collapsed early. All climate patterns were shifted earlier in 1998 climate regime shift period. Abrupt negative shift was detected in sea water temperature of south East/ Japan Sea (1999) and East China Sea (2002).

Interpretation: This study will help to project the future scenario of these East Asian marginal sea ecosystems under upcoming climate regime shift in North Pacific

Key words: Climate regime shift, EastAsian marginal sea, Fish species, Seawater temperature, Synchronicity

To investigate the synchronous pattern of regime shifts among the climate patterns in north Pacific, sea water temperature and major fish species in East Asian marginal sea waters for 1976, 1988 and 1998 climate regime shift

\begin{tabular}{|l|l|}
\hline \multicolumn{2}{|c|}{ Data collection and analysis } \\
\hline \multicolumn{2}{|c|}{ Data } \\
\hline - Atmospheric condition data & - Sequential t-test analysis \\
- Sea water temperature data & - Cluster analysis \\
- Sea water temperature data & - Low pass filtering \\
- Fisheries data & - Sea level fluctuation analysis \\
- Volume transport data & \\
\hline
\end{tabular}

Major contents

- Regime shifts in the north Pacific large scale climate indices

- Regime shifts in seawater temperature of East Asian marginal sea

- Regime shifts in the fisheries resources of East Asian marginal sea

- Synchrony between climate pattern in north Pacific and sea water temperature in East Asian marginal sea

Summary

- During the 1976 climate regime shift period, climate indices were shifted for longer duration; abrupt shift pattern in Pacific decadal oscillation, north Pacific index and El Nino Southern Oscillation played a major role during this period, earlier positive shifts were detected in most of the sea water temperature of all areas without south East / Japan sea.

How to cite : Rahman, S.M.M., H.K. Jung, H.J. Park, J.M.Park and C.I. Lee: Synchronicity of climate driven regime shifts among the EastAsian marginal sea waters and major fish species. J. Environ. Biol., 40, 948-961 (2019). DOI : http://doi.org/10.22438/jeb/40/5(SI)/SI-18 


\section{Introduction}

East/Japan Sea, East China Sea and Yellow Sea are three contiguous seas that comprise East Asian Marginal Sea with their unique oceanographic features. It is one of the largest areas of world ocean capture fisheries; however, abrupt shift of major fish species in commercial catches has been a big issue since long period. Alternation from cold water fishery to warm water fishery, sudden collapse or enhance of commercial species are major concern in this area for last couple of decades. Climate driven regime shift in marine environment and consequently in ecosystem means that the abrupt change from a steady state to another steady state due to the forcing from climate regime shift. One steady state or regime may last for several decades to few years. Underlying processes and synchronicity of regime shifts in marine environment and major fisheries resources are still largely unknown for East Asian Marginal Seas; however, large scale climate variability has been suggested one of the key factors. Based on long term time series data; synchronous pattern of major regime shifts in north Pacific major climate system, and marine environment and major fish species in East Asian marginal sea were investigated in this study.

Climate driven regime shift was observed among the major large marine ecosystems in north Pacific region since beginning $20^{\text {th }}$ century (Zhang et al., 2000; Zhang et al., 2004; Gong et al., 2007; Kim et al., 2007; Lee et al., 2008; Kang et al., 2012; Gong and Suh, 2013). Two large climate regime shift events were well detected in 1976/77 (hereafter 1976) and 1988/89 (hereafter 1988); however, more recently in 1998 regime shift also was observed in this region. In the East Asian marginal sea, regime shifts in temperature have been reported in previous studies (Rebstock and Kang, 2003;Gordon and Giulivi, 2004; Zhang et al., 2004; Kim et al., 2007; Jung et al., 2007; Kim et al., 2008; Lee et al., 2008; Kang et al., 2012, Jung et al., 2017). An early winter (Dec-Feb) warming trend after 1977 CRS and a winter (Jan-Mar) warming trend after 1988 CRS in both north and south East / Japan Sea, northern East China Sea and eastern Yellow Sea were observed (Kang et al., 2012). A positive shift of temperature at $10 \mathrm{~m}$ and $50 \mathrm{~m}$ depths in most of East Asian Marginal Sea during late 1980s were detected (Rebstock and Kang, 2003).

Fluctuations in abundance of major commercial species in East/Japan Sea, East China Sea and Yellow Sea with longterm change in oceanic and atmospheric condition were also observed by Park et al. (1998), Zhang et al. (2004), Kim et al. (2007), Jung et al. (2007) and Kim et al. (2008). Commercial catches in East/Japan Sea over the last four decades have gone through some remarkable changes in species composition (Zhang et al., 2004). In 1970's and 1980's, walleye pollock was dominant followed by common squid whereas in 1990's and 2000's, walleye pollock was replaced to a marked extent by common squid. In East China Sea, Pacific anchovy, hairtail and yellow croaker dominated during 1960's, whereas chub mackerel, filefish, and Japanese sardine in 1970's (Kim et al., 2008). In 1980's and 1990's, anchovy, chub mackerel and common squid dominated in catch composition. In Yellow Sea, hairtail and yellow croaker were dominant species in1960's and 1970's. In 1980's and 1990's, those species became less common while yellow croaker, flounder and Pacific anchovy catches increased. At least four different fishery regimes occurred in all these marine waters in terms of dominant fish species (Jung et al., 2007): (1) Pacific saury (1968-1976); (2) walleye pollock (1977-1982); (3) Japanese sardine (1983-1990) and (4) common squid (1991-2006).

However, information of synchronous pattern in sea water temperatures and major fish species in EastAsian marginal sea under recent climate regime shift are limited. Most of the previous studies have not accessed via comprehensive analyses due to their emphasis on limited study area (e.g. south East/Japan Sea), and have mainly focused on single climate pattern (e.g. El Niño Southern Oscillation) or targeted only single fish species (e.g. Pacific saury). Moreover, only few studies (Kim et al., 2007; Rahman and Lee, 2012) have been conducted on the major fish species assemblage pattern related to CRS. Based on long term time series, in the present study, the synchronous pattern of regime shifts among climate patterns in north Pacific, sea water temperature and major fish species in East Asian marginal sea for 1976, 1988 and 1998 regime shifts were investigated.

\section{Materials and Methods}

Large scale climate patterns in north Pacific: Pacific decadal oscillation (Mantua et al., 1997), north Pacific index (Trenberth and Hurrel, 1994) which depict the changes in intensity of Aleutian low pressure system (Beamish et al.,1997), Arctic oscillation (Thomson and Wallace, 1998), Siberian high pressure (Gong and Ho, 2002) and East Asian winter monsoon (Jhun and Lee, 2004) indices were selected as major large scale climate-ocean patterns in the north Pacific (Beamish et al.,. 2000; Tian et al., $2004,2006)$. The data periods for all these climate indices were from 1950 to 2015 .

Seawater temperature in East Asian marginal sea: Four regions in the East Asia Marginal Sea were selected as a representative area of the (1) north East / Japan Sea $\left(40^{\circ}-42^{\circ} \mathrm{N}\right.$, $\left.133^{\circ}-137^{\circ} \mathrm{E}\right) ;(2)$ south East / Japan Sea $\left(35^{\circ}-38^{\circ} \mathrm{N}, 130^{\circ}\right.$ $\left.133^{\circ} \mathrm{E}\right)$; (3) East China Sea $\left(30^{\circ}-32^{\circ} \mathrm{N}, 124^{\circ}-129^{\circ} \mathrm{E}\right)(4)$ Yellow Sea $\left(35^{\circ}-37^{\circ} \mathrm{N}, 123^{\circ}-126^{\circ} \mathrm{E}\right)$ (Fig. 1). Time series of $10 \mathrm{~m}, 50 \mathrm{~m}$ and $100 \mathrm{~m}$ sea water temperatures of winter time (Jan.-Mar.) were collected from the World Ocean Database (WOD13, www.nodc.noaa.gov).

Fisheries data: Ten major fish species were selected among total of 62 species from the Korea Fisheries Association database 
Table 1 : Characteristics of 10 major commercial species in Korean waters of EastAsian Marginal Sea

\begin{tabular}{|c|c|c|c|c|}
\hline Species & Habitat & Distribution & Spawning ground & $\begin{array}{l}\text { Responses of major climate/ } \\
\text { oceanographic factors }\end{array}$ \\
\hline $\begin{array}{l}\text { Walleye } \\
\text { pollock }\end{array}$ & Semi-demersal & $\begin{array}{l}\text { Coastal areas of the } \\
\text { north East/Japan Sea }\end{array}$ & $\begin{array}{l}\text { Shallow coastal water } \\
\text { of Won-San Bay* in }\end{array}$ & $\begin{array}{l}\text { Sea water temperature (Lee and Kim, 2010; } \\
\text { Lee et al., 2008), North-eastern Pacific Pressure } \\
\text { East/Japan Sea Index (Kang et al., 2000). }\end{array}$ \\
\hline $\begin{array}{l}\text { Pacific } \\
\text { cod }\end{array}$ & Demersal & $\begin{array}{l}\text { Coastal areas of the } \\
\text { East/Japan Sea }\end{array}$ & $\begin{array}{l}\text { Jinhae Bay in SES, } \\
\text { western Honshu } \\
\text { (Noto Peninsula) }\end{array}$ & $\begin{array}{l}\text { Negative effect of } A O \text { on the total catch } \\
\text { (Chung et al., 2013) }\end{array}$ \\
\hline $\begin{array}{l}\text { Common } \\
\text { Squid }\end{array}$ & Pelagic & $\begin{array}{l}\text { Coastal areas of the } \\
\text { East/Japan Sea }\end{array}$ & South East/Japan Sea & $\begin{array}{l}\text { Stability of the warm water, bottom topography, } \\
\text { and pycnocline depth (Sakurai et al., 2000) }\end{array}$ \\
\hline $\begin{array}{l}\text { Japanese } \\
\text { anchovy }\end{array}$ & Pelagic & $\begin{array}{l}\text { Korea Strait and the southern } \\
\text { Yellow Sea during winter; migrate } \\
\text { shoreward to the southern coast } \\
\text { of Korea during summer }\end{array}$ & $\begin{array}{l}\text { Southern coast of } \\
\text { Korean peninsula }\end{array}$ & $\begin{array}{l}\text { Volume transport of the Tsushima Warm Current } \\
\text { (Kim, 1992; Choo and Kim, 1998) }\end{array}$ \\
\hline $\begin{array}{l}\text { Japanese } \\
\text { sardine }\end{array}$ & Pelagic & $\begin{array}{l}\text { Southern waters of the Korean } \\
\text { Peninsula during winter and migrate } \\
\text { north in the summer to feed near } \\
45^{\circ} \mathrm{N} \text { along the western coast of } \\
\text { East/Japan Sea }\end{array}$ & $\begin{array}{l}\text { Southern coast of } \\
\text { Korean peninsula }\end{array}$ & $\begin{array}{l}\text { Kuroshio current plays a critical role to transport } \\
\text { sardine eggs and larvae (Zhang et al., 2000; } \\
\text { Yatsu et al., 2005) }\end{array}$ \\
\hline $\begin{array}{l}\text { Pacific } \\
\text { herring }\end{array}$ & Pelagic & $\begin{array}{l}\text { Coastal areas of the East/Japan } \\
\text { Sea }\end{array}$ & $\begin{array}{l}\text { Jinhae Bay in South } \\
\text { East/Japan Sea }\end{array}$ & $\begin{array}{l}\text { ENSO events, surface water temperature } \\
\text { (Beamish et al., 2008) }\end{array}$ \\
\hline $\begin{array}{l}\text { Pacific } \\
\text { saury }\end{array}$ & Pelagic & $\begin{array}{l}\text { Tsushima Warm Current } \\
\text { region and Hokkaido** }\end{array}$ & $\begin{array}{l}\text { Tsushima Warm Current } \\
\text { region and Hokkaido** }\end{array}$ & $\begin{array}{l}\text { Sea water temperature in the Tsushima Warm } \\
\text { Current region (Gong and Suh, 2013) }\end{array}$ \\
\hline $\begin{array}{l}\text { Chub } \\
\text { Mackerel }\end{array}$ & Pelagic & $\begin{array}{l}\text { Western, Southern and } \\
\text { South-eastern seas around Korean } \\
\text { peninsula, in the East China Sea, } \\
\text { and around Japan }\end{array}$ & $\begin{array}{l}\text { Western, Southern and } \\
\text { South-eastern seas } \\
\text { around Korean peninsula, } \\
\text { in the East China Sea }\end{array}$ & $\begin{array}{l}\text { SST, Salinity, Chl-a, zooplankton biomass(Choi et } \\
\text { al., 2000) }\end{array}$ \\
\hline Hairtail & Semi-demersal & $\begin{array}{l}\text { South western waters off Jeju } \\
\text { Island in Jan. to Mar.; migrates } \\
\text { central parts of the East Yellow } \\
\text { Sea in July-Aug }\end{array}$ & $\begin{array}{l}\text { Central parts of the east } \\
\text { coast of Yellow Sea }\end{array}$ & $\begin{array}{l}\text { Bottom water temp. of the western Jeju Island } \\
\text { (Kim et al., 1992), EINiño (Kim et al., 2005) }\end{array}$ \\
\hline $\begin{array}{l}\text { Small } \\
\text { Yellow } \\
\text { Croaker }\end{array}$ & Semi-demersal & $\begin{array}{l}\text { Migrate to East China Sea in } \\
\text { winter and return to the Yellow } \\
\text { Sea to spawn in spring } \\
\text { (Kim et al., 2007) }\end{array}$ & $\begin{array}{l}\text { Eastern part of the } \\
\text { Yellow Sea }\end{array}$ & $\begin{array}{l}\text { Variability in water temp. at } 75 \text { m depth in the Yellow } \\
\text { Sea (Kim et al., 1997), Yellow Sea bottom cold water } \\
\text { (Baik et al., 2005) }\end{array}$ \\
\hline
\end{tabular}

*Won-San Bay: Democratic People's Republic of Korea; **Hokkaido: Western Kyushu Island, Japan; ENSO: El Niño Southern Oscillation

(KFA, 2014) which shared more than $50 \%$ of total catch cumulatively since 1970's; walleye pollock (Gaduschalcogrammus), Pacific cod (Gadus macrocephalus), common squid (Todarodes pacificus), Japanese anchovy (Engraulis japonicas), Japanese sardine (Sardinopsmelan ostictuc), Pacific herring (Clupeapallasii), Pacific saury (Cololabissaira), chub mackerel (Scomber japonicas), hairtail (Trichiurus lepturus) and yellow croaker (Larimichthyspolyactis). Different characteristics of these fish species are given in Table 1.
Statistical analysis: Butterworth low pass filtering was used for smoothing time series (cut off length 10 years) to identify only decadal fluctuation patterns in databases (Jung et al., 2017).Pearson correlation was performed by SPSS 12 to identify the relationship between north Pacific climate pattern and sea water temperature of East Asian marginal sea. A sequential t-test analysis of regime shift (STARS, www.beringclimate.noaa.gov) developed by Rodionov (2004) was used to detect regime shifts in time series of climate indices, sea water temperature, and fish 


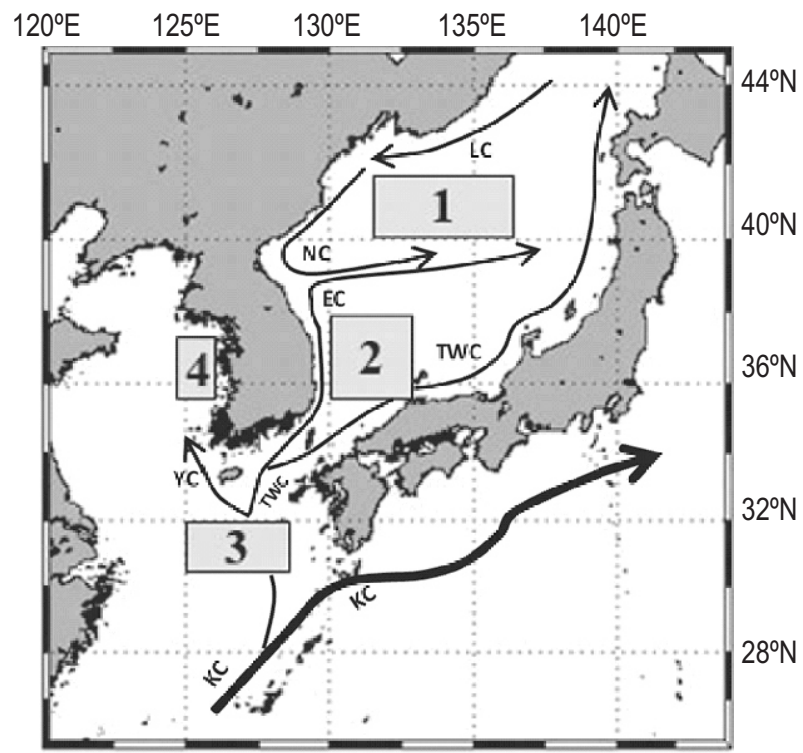

Fig. 1 : Amap showing the study areas and major current systems in East Asian Marginal Sea; (1) north East/Japan Sea, (2) south East/Japan Sea , (3) East China Sea and (4) Yellow Sea . KC: Kuroshiocurrent, TWC: Tsushima warm current, YC: Yellow current, EC: East Korean warm current, NC: North Korean cold current, LC: Liman current.

species abundance in this study. STARS results are determined by the cut-off length for proposed regimes (L), and Huber weight parameters $(H)$, which defines the range of departure from observed mean beyond which observations are considered as outliers. Significant level $(p)$,cut-off length (I) and Huber weight parameters $(h)$ are $0.1,10$ and 1 respectively. A hierarchical cluster analysis with group-average linkage was performed on fish assemblage data obtained from 1975 to 2015 based on Bray-Curtis similarity using PRIMER package version 6, to determine interannual change of fish community (Clarke and Gorley, 2006). Fish assemblages among the same period were compared using a non-metric multidimensional scaling ordination (nMDS) based on above similarity. These analyses were used to generate dendrograms and the classified main groups were represented in the nMD Splot. Analysis of similarities permutation test (ANOSIM) was used to compare the differences in fish assemblages among the postulated groups.

\section{Results and Discussion}

Using STARS analysis, we detected regime shifts pattern and oscillation synchrony of major climate patterns in north Pacific (Fig. 2 and Table 2). 1976 CRS was detected for a longer duration period(1970-1979); a negative shift in El Niño Southern Oscillation (1970) and a positive shift in Arctic oscillation (1972) were detected earlier. Shifts were detected in north Pacific index (1975), Pacific decadal oscillation (1977),El Niño Southern Oscillation (1977), and East Asian winter monsoon (1979) during thisperiod. North Pacific index, Pacific decadal oscillation, and El
Niño Southern Oscillation were shifted most abruptly in this period. 1988 CRS was detected in most of the climate indices within short period; Arctic oscillation (1987), Pacific decadal oscillation (1989), north Pacific index (1988), Siberian high pressure (1989), and East Asian winter monsoon (1987). Arctic oscillation, East Asian winter monsoon and Siberian high pressure shifted most abruptly during this period. For 1998 CRS, earlier shifts occurred in Arctic oscillation (1995), north Pacific index (1995), East Asian winter monsoon (1995), Siberian high pressure (1996), and El Niño Southern Oscillation (1997). East Asian winter monsoon and Siberian high pressure shifted most abruptly during CRS period. Recently, abrupt shifts were observed in East Asian winter monsoon (2004), Pacific decadal oscillation (2007), El Niño Southern Oscillation (2007), north Pacific index (2006), and Siberian high pressure (2006). 1988 CRS was the most abrupt shift recorded since 1950 in north Pacific when most of the climate indices were shifted within short time (1987-1989).

Regime shifts in sea water temperatures in four study regions are illustrated in Figs.3, 4 and Table 2. During the period of 1976 CRS, an earlier positive shift was detected in East China Sea (1970) and YS (1972). South East / Japan Sea (1975) was shifted negatively whereas a positive shift was observed in the north East/Japan Sea (1976). 1988 CRS was demonstrated as sea water temperatures of all are as were shifted positively within very short time (1985-1991) and a warm regime was observed in this period. 1998 CRS was marked as a negative shift in south East/Japan Sea (1999) and in East China Sea (2002); and a positive shift in north East/Japan Sea (2001). So, cold temperature regimes were observed both in south East/Japan Sea and East China Sea regions, however, warm temperature regimes still continued in north East / Japan Sea and Yellow Sea which started after 1988 CRS. Recently after 1998 CRS, SWT in most of the regions shifted negatively; south East/Japan Sea (2008), north East/Japan Sea (2010), East China Sea (2013), and Yellow Sea (2007). After 1998 regime shift period, sea water temperature in most of the regions shifted to further colder regime.

Regime shift of major 10 species in four study regions are illustrated in Fig.5 and Table 2. In 1976 regime shift period, an earlier positive shift was detected in cold water demersal walleye pollock and a negative shift in warm water common squid in 1973. Two small pelagic species (Japanese sardine and Pacific saury) were shifted most abruptly and inversely in 1977. Also positive abrupt shifts were detected in Japanese anchovy (1973), hairtail (1973) and yellow croaker (1972). In 1988 regime shift period, Japanese sardine and walleye pollock collapsed quite early in 1983 and 1985 respectively. Abrupt positive shifts were detected in yellow croaker (1987), Pacific herring (1988), common squid (1989), chub mackerel (1989) and Japanese anchovy (1991); and negative shifts were detected in hairtail (1988) and Pacific cod (1989). In 1998 regime shift period, abrupt positive shifts 

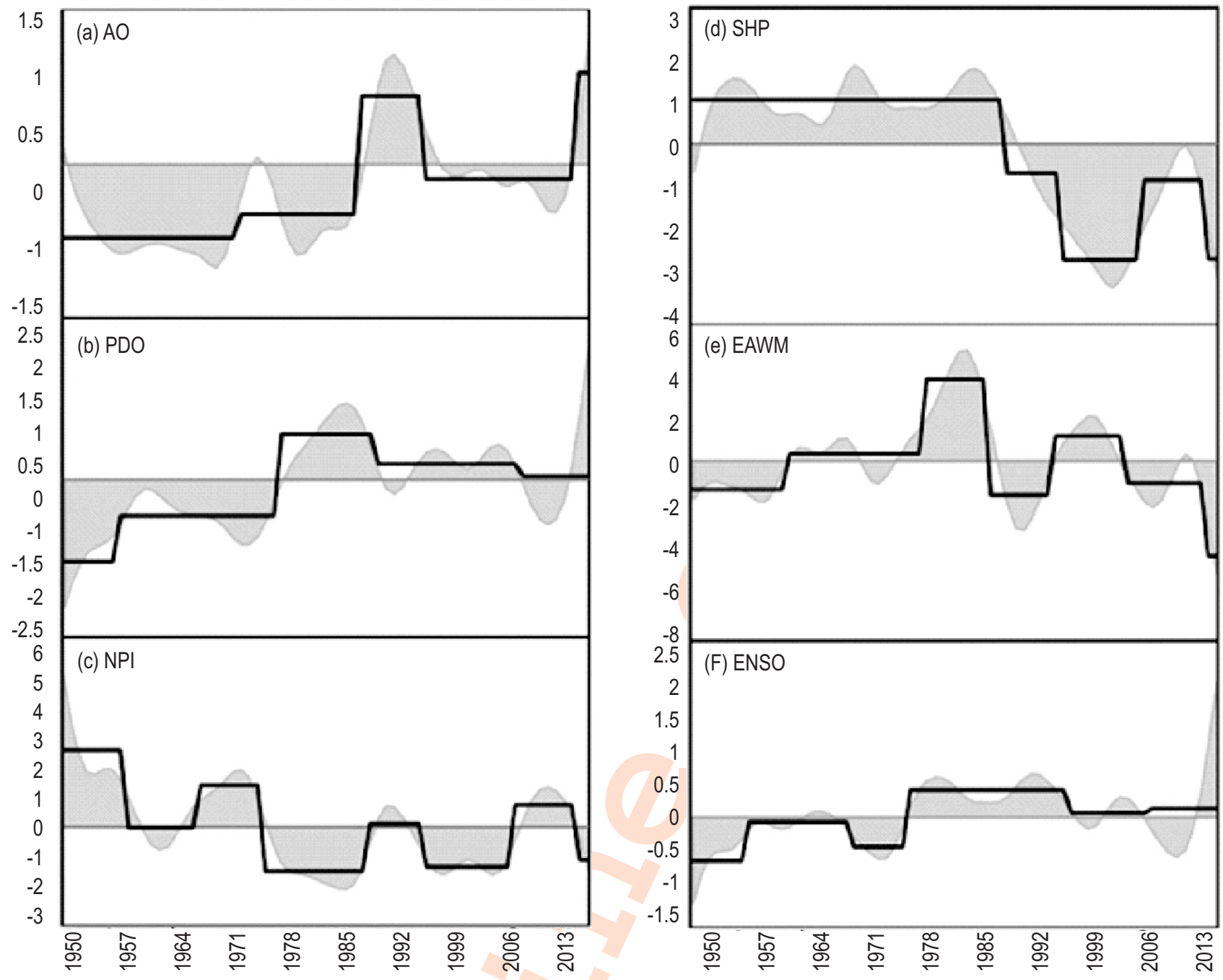

Fig. 2 : Anomaly values (grey shaded, low pass butter worth filtered with 10-yr cut-off period) and step changes in the anomalies (solid black line) detected by sequential t-test analysis of regime shift(STARS) of major climate indices. AO: Arctic Oscillation; SHP: Siberian High Pressure; EAWM: East Asian Winter Monsoon; PDO: Pacific Decadal Oscillation; NPI: North Pacific Index; ENSO: EI Niño Southern Oscillation.

were detected in Japanese anchovy (1998), Pacific herring (1996), Pacific saury (1996) and Pacific cod (2001); negative shifts were detected in Pacific sardine (1998) and chub mackerel (2001). Abrupt collapses were observed in hairtail (1997) and yellow croaker (1998); common squid was shifted positively in 1995. Recently, positive abrupt shifts were detected in Pacific herring (2006) and Pacific cod (2007); negative abrupt shifts were detected in common squid (2006) and yellow croaker (2005). Also negative shifts were detected in Pacific saury (2004) and hairtail (2010). The hierarchical clustering and nMDS ordination plot based on total fish assemblage data allowed three distinct groups (Group A: 1965 to 1974, Group B: 1993 to 2015, and Group C: 1975 to 1992), which were divided into two subgroups (Fig. 6). The fish community structure in the EAMS waters differed significantly among three periods (ANOSIM test, $p<0.001$ ). Group A mostly consisted warm species (dominant species; squid, anchovy, and saury) that were different other periods. Group B mainly included warm species (dominant species; anchovy, squid, and hairtail) revealing that the environmental conditions changed again from cold regime to warm regime. In contrast, Group C represented cold fish community structure that mainly consisted of cold species (dominant species; walleye pollock and sardine).

Correlation statistics among the climate indices and sea water temperatures are illustrated in Table 3. In north East / Japan Sea region, sea water temperature $(10 \mathrm{~m})$ was significantly correlated with Arctic oscillation, Siberian high pressure and East Asian winter monsoon whereas sea water temperature $(50 \mathrm{~m})$ was significantly correlated with Arctic oscillation, Siberian high pressure, East Asian winter monsoon, and El Niño Southern Oscillation. Also, SWT $(100 \mathrm{~m})$ had strong correlation with 
Table 2 : Regime shifts detected in climate indices in north Pacific, sea water temperature and major ten species catch anomaly in East Asian marginal sea

\begin{tabular}{|c|c|}
\hline & Regime shifts \\
\hline \multicolumn{2}{|l|}{ Climate Indices } \\
\hline Arctic Oscillation & $1972,1987,1995,2014$ \\
\hline Pacific Decadal Oscillation & $1957,1977,1989,2007$ \\
\hline North Pacific Index & $1958,1967,1975,1988,1995,2006,2014$ \\
\hline Siberian High Pressure & $1989,1996,2006,2014$ \\
\hline EastAsian Winter Monsoon & $1962,1979,1987,1995,2004,2014$ \\
\hline El Niño Southern Oscillation & $1957,1970,1977,1997,2007$ \\
\hline \multicolumn{2}{|l|}{ Sea water temperature } \\
\hline North East/Japan Sea (10m) & $1962,1970,1989,2001,2010$ \\
\hline North East/Japan Sea (50m) & $1962,1976,1987,1994,2001,2011$ \\
\hline North East/Japan Sea (100m) & $1962,1976,1983,1991,1999,2011$ \\
\hline South East/Japan Sea $(10 \mathrm{~m})$ & $1977,1987,2000,2009$ \\
\hline South East/Japan Sea $(50 \mathrm{~m})$ & $1963,1975,1985,1991,1999,2008$ \\
\hline South East/Japan Sea $(100 \mathrm{~m})$ & $1964,1976,1986,2000,2010$ \\
\hline East China Sea $(10 \mathrm{~m})$ & $1961,1970,2001,2013$ \\
\hline East China Sea $(50 \mathrm{~m})$ & $1961,1970,1978,1987,2002,2014$ \\
\hline East China Sea $(100 \mathrm{~m})$ & $1958,1964,1971,1980,1988,2003,2012$ \\
\hline Yellow Sea $(20 \mathrm{~m})$ & $1964,1972,1989,2007$ \\
\hline \multicolumn{2}{|l|}{ Major fish species } \\
\hline Japanese anchovy & $1959,1967,1973,1991,1998,2014$ \\
\hline Japanese sardine & $1977,1983,1990,1998$ \\
\hline Pacific herring & $1988,1996,2006$ \\
\hline Pacific saury & $1956,1965,1977,1983,1996,2004$ \\
\hline Common squid & $1959,1973,1989,1995,2006$ \\
\hline Chub mackerel & $1969,1976,1989,2001,2011$ \\
\hline Walleye pollock & $1973,1985,1993$ \\
\hline Pacific cod & $1989,2001,2007$ \\
\hline Hairtail & $1968,1973,1988,1997,2010$ \\
\hline Yellow croaker & $1972,1987,1998,2005$ \\
\hline
\end{tabular}

Table 3 : Correlation statistics between sea water temperatures and climate variability

\begin{tabular}{|c|c|c|c|c|c|c|c|c|c|c|}
\hline & $\operatorname{NES}(10 \mathrm{~m})$ & $\operatorname{NES}(50 \mathrm{~m})$ & $\operatorname{NES}(100 \mathrm{~m})$ & $\operatorname{SES}(10 \mathrm{~m})$ & $\operatorname{SES}(50 \mathrm{~m})$ & SES $(100 \mathrm{~m})$ & $\operatorname{ECS}(10 \mathrm{~m})$ & $\operatorname{ECS}(50 \mathrm{~m})$ & $\operatorname{ECS}(100 \mathrm{~m})$ & $\mathrm{YS}(20 \mathrm{~m})$ \\
\hline AO & .313 & .442 & .065 & .450 & .492 & .470 & .100 & .395 & .359 & .657 \\
\hline PDO & .182 & .240 & .166 & -.226 & .057 & -.017 & -.367 & .019 & .059 & .307 \\
\hline NPI & -.197 & -.153 & -.217 & .135 & -.091 & -.046 & .331 & -.031 & -.184 & -.291 \\
\hline SHP & -.406 & -.309 & -.535 & -.285 & -.222 & -.109 & .205 & -.121 & -.227 & -.445 \\
\hline EAWM & -.334 & -.403 & -.229 & -.310 & -.162 & .016 & .014 & -.001 & -.159 & -.351 \\
\hline ENSO & .186 & .277 & .083 & -.032 & .224 & .100 & -.441 & -.137 & -.044 & .366 \\
\hline
\end{tabular}

NES: north East/Japan Sea; SES: south East/Japan Sea; ECS: East China Sea; YS: Yellow Sea; AO: Arctic Oscillation; SHP: Siberian High Pressure; EAWM: EastAsian Winter Monsoon; PDO: Pacific Decadal Oscillation; NPI: North Pacific Index; ENSO: EI Niño Southern Oscillation; Single and double asterisks represent significance at $p<0.05$ and $p<0.01$, respectively

Siberian high pressure. In south East/Japan Sea, sea water temperature $(10 \mathrm{~m})$ had some significant correlations with Arctic oscillation, Siberian high pressure and East Asian winter monsoon whereas sea water temperature $(50 \mathrm{~m}$ and $100 \mathrm{~m})$ showed significant correlations with Arctic oscillation only. So, both in north East/Japan Sea and south East / Japan Sea, Arctic oscillation, Siberian high pressure and East Asian winter monsoon had strong influence on sea water temperature. In ECS, sea water temperature $(10 \mathrm{~m})$ had significant relationship with Pacific decadal oscillation, north Pacific index and El Niño Southern oscillation whereas sea water temperature $(50 \mathrm{~m}$ and $100 \mathrm{~m}$ ) had significant correlation with Arctic oscillation only. So, Siberian high pressure and East Asian winter monsoon did not influence this region. In shallow YS, SWT $(20 \mathrm{~m})$ was significantly correlated with all climate indices. In the period of 1976 CRS, Pacific decadal oscillation, north Pacific index and El Niño 
North East / Japan Sea

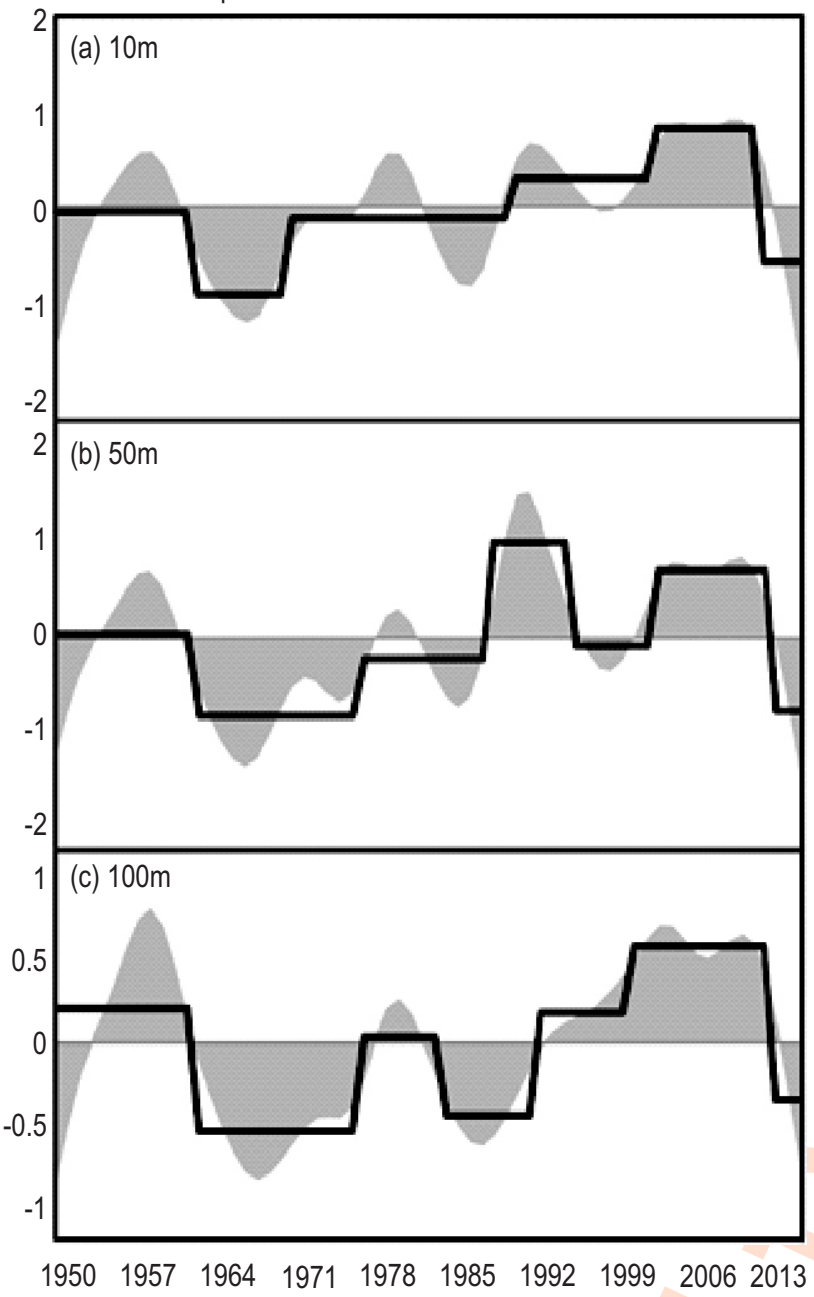

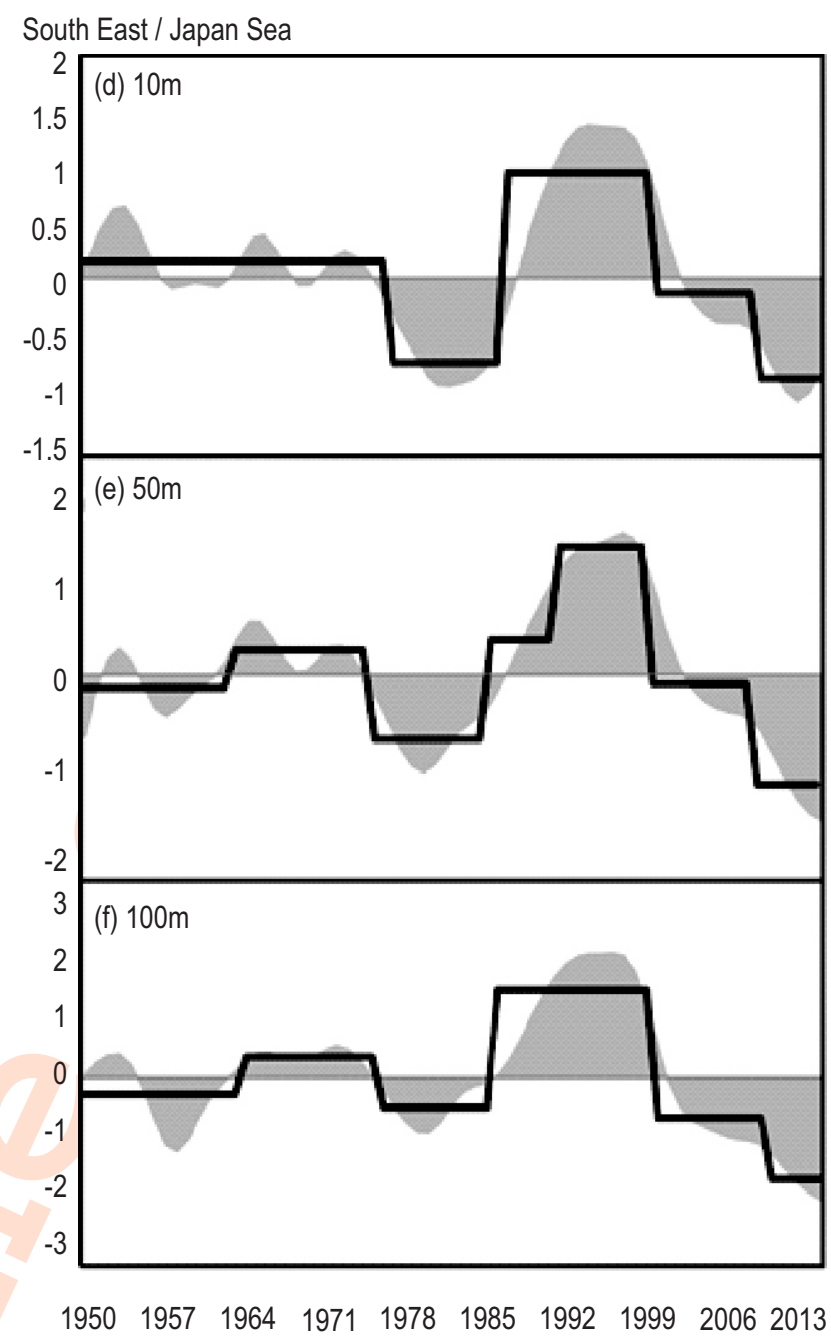

Fig. 3 : Time series of sea water temperature anomaly at $10 \mathrm{~m}, 50 \mathrm{~m}$, and $100 \mathrm{~m}$ depths in north East/Japan Sea, south East/Japan Sea in winter (smoothed by a low-pass Butterworth filter with 10-yr cut-off period). The solid black line indicates the step changes in the anomalies detected by sequential t-testanalysis of regime shift (STARS).

Southern Oscillation were shifted most abruptly; in south East/Japan Sea, sea water temperature was clearly shifted to colder regime just after 1976, however, in north East/Japan Sea, it was shifted to warmer regime from colder regime period though it persisted for short period. Also, colder regime prevailed in East China Sea and Yellow Sea region after 1976 CRS though it was not detected in Yellow Sea region in this study. This CRS period was evident with intensification of ALP with lower average temperature in Central Pacific with an active winter monsoon in East Asian region. Enhanced ALP from mid-1970's had a significant impact on positive phases of Pacific decadal oscillation through mid-latitude atmosphere-ocean interactions over north Pacific. So, decadal fluctuation patterns of Pacific decadal oscillation and ALP have direct influence on upper layer sea water temperatures in Central Pacific and in East Asian Marginal Sea (Miller et al., 2004; Yatsu et al., 2013). Limsakul et al. (2001) mentioned significant association between intensification of
Aleutian low pressure system and enhancement of winter time East Asian winter monsoon over Japanese waters (both northern and southern coast) after 1976 CRS. Gordon and Giulivi (2004) mentioned a direct influence of Pacific decadal oscillation to sea water temperature of south East/Japan Sea, whereas Chiba et al. (2005) mentioned a direct influence of Pacific decadal oscillation for sea water temperature of north East Sea.

1988 CRS was evident with the shift of major climate indices; attenuation of ALP with higher average temperature in Central Pacific, Arctic oscillation was in positive phase with a lower pressure prevailed in polar region, negative phase of Siberian high pressure and a weak monsoon prevailed in East Asian region. So, after this CRS, surface pressure was low in both polar and Siberia regions. This helps jet stream to blow strongly and keep cold Arctic air locked in polar region and brings weaker chilly wind over East/Japan Sea, East China Sea and 

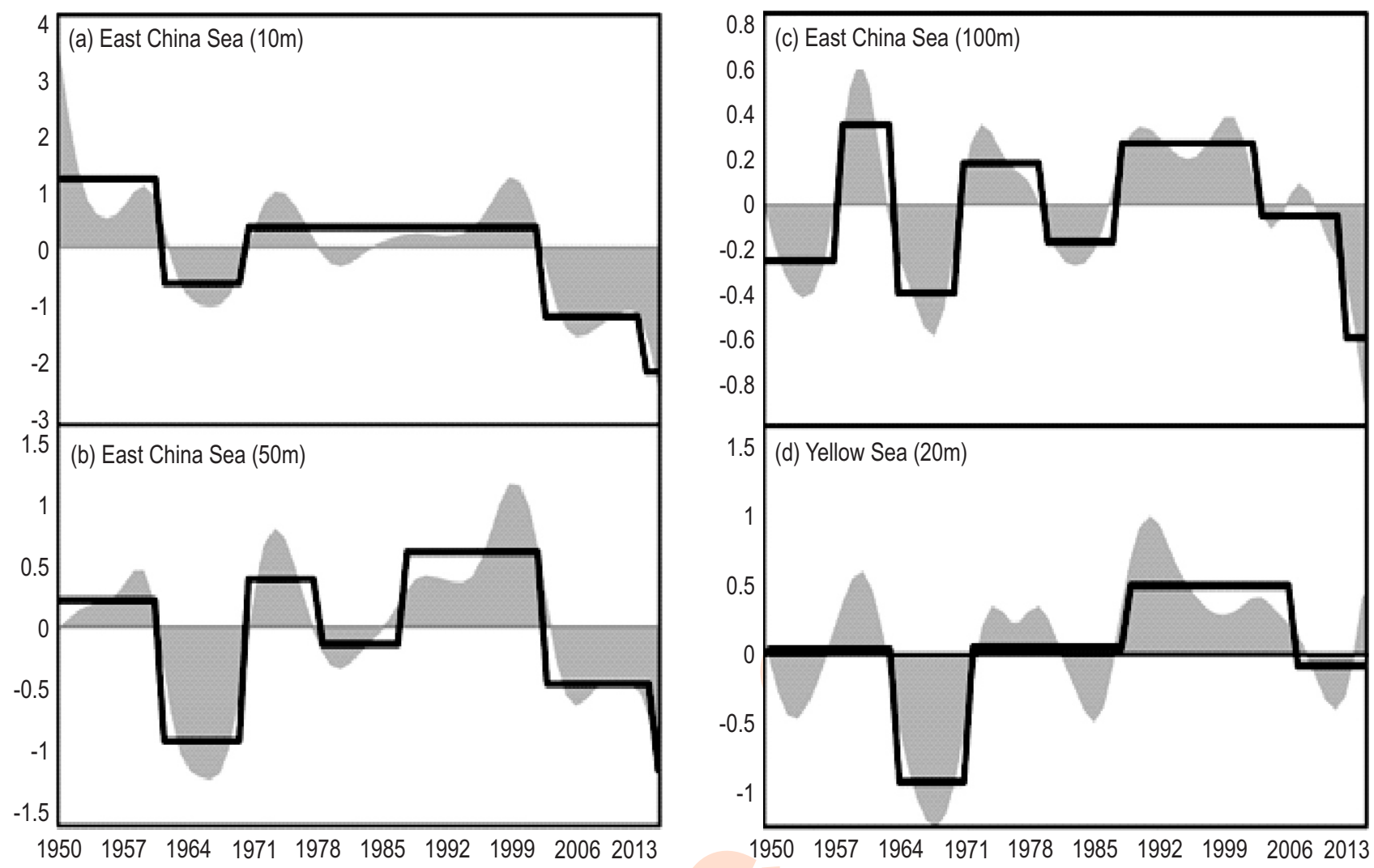

Fig. 4 : Time series of sea water temperature anomaly at $10 \mathrm{~m}, 50 \mathrm{~m}$, and $100 \mathrm{~m}$ depth in East China Sea and at $20 \mathrm{~m}$ depth in Yellow Sea in winter (smoothed by a low-pass Butterworth filter with 10-yr cut-off period). The solid black line indicates the step changes in the anomalies detected by sequential t-testanalysis of regime shift (STARS).

Yellow Sea; and consequently mild winters occurred after 1988 CRS. Atmospheric forcing is one of the primary cause of low frequency of sea water temperature variability in East Asian Marginal Seas (Yeh et al., 2010). The large scale atmospheric circulation over East Asian Marginal Sea waters dominated by two major atmospheric forcing, Siberian high pressure centered in Eurasia and ALP centered at Alaska, north Pacific. Changes in intensity of these two pressure systems significantly control the strength of wind forcing over this region in winter (Fig. 7). The pressure gradient between Siberian high pressure and north Pacific index control the intensity of East Asian winter monsoon (Jhun and Lee, 2004; Limsakul et al., 2001). There are significant correlation $(r=0.55)$ between pressure gradient (between Siberian high pressure and north Pacific index) and East Asian winter monsoon since 1950.Therefore, when mean sea level pressure gradient between these two pressure systems reduced, wind over this region weakened, resulting in an increase in sea water temperature due to reduction of sensible heat flux with weak transport of cold water beneath mixed layer and opposite pattern occurred when pressure gradient increased. Significant increased pressure gradient was observed around mid of 1970's to mid of 1980's contributed to shift from warm temperature regime to cold temperature regime in East Asian Marginal Sea; and a significant decreased pattern was observed from late 1980's contributed to warm regime shifting from cold regime.

Volume transport in East Asian Marginal Sea waters from different current sources also affect upper layer temperature profile. Decadal pattern of ALP-Pacific decadal oscillation coupled system can influence north Pacific subtropical gyre oscillation; which further influence Kuroshio Current volume transport in the East Asian Marginal Sea waters. Kuroshio Current, however, control the intrusion of Tsushima Warm Current and Taiwan Current volume transport into the East China Sea and south East/Japan Sea(Gordon and Giulivi, 2004, Chiba et al., 2005). Gordon and Giulivi(2004) reported close association between Kuroshio Current and Tsushima Warm Current; after 1976 CRS, the Tsushima Warm Current weakened due to enhanced meandering of Kuroshio Current. Weak Tsushima Warm Current in Korea Strait after 1976 CRS was one of the reasons for shifting cold temperature regime from warmer one in East/Japan Sea upper layer. On the other hand, after 1988 CRS, Kuroshio Current became weaken whereas Tsushima Warm Current became strong which contributed a shift from cold to warm temperature regime in East/Japan Sea. 

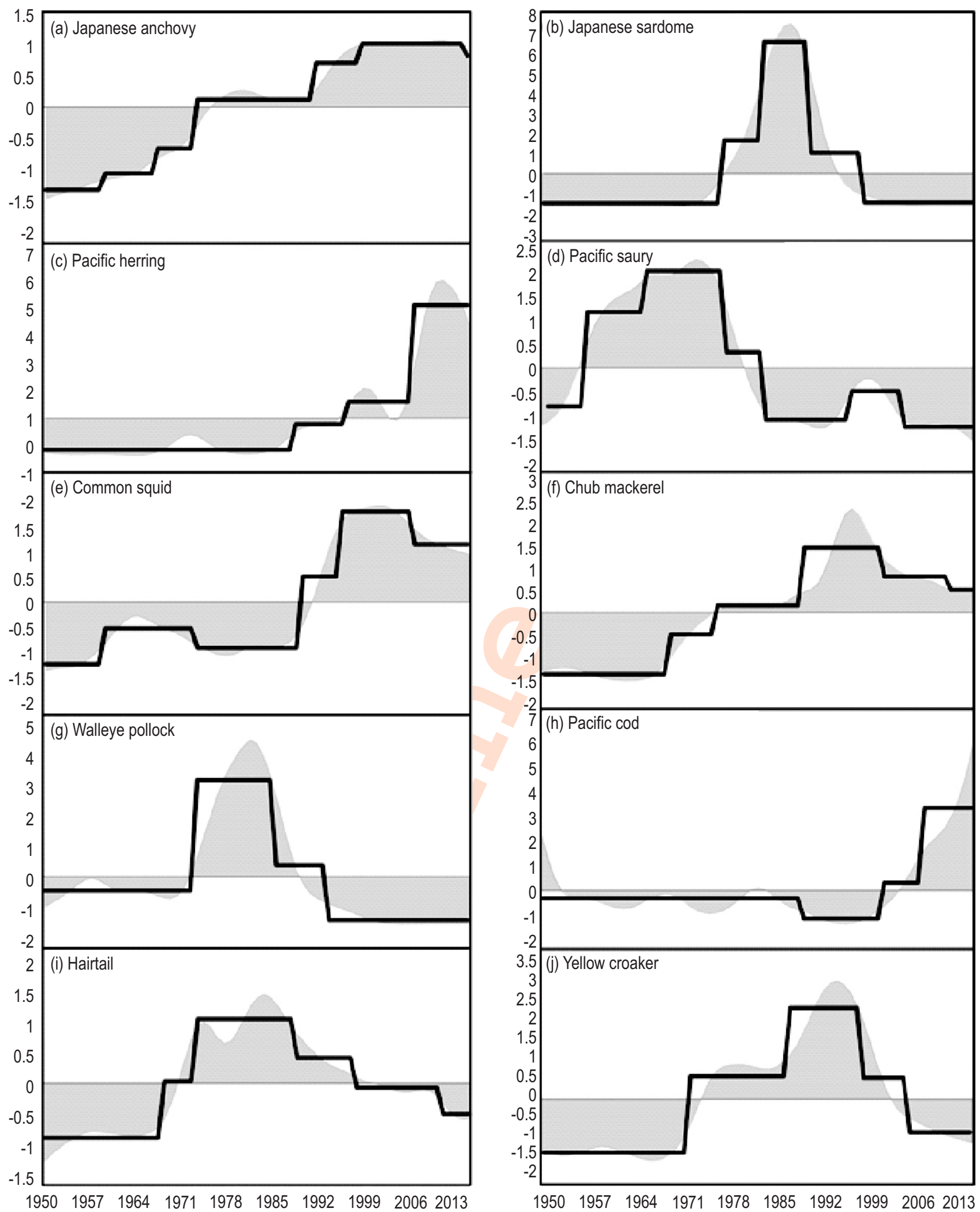

Fig. 5 : Time series changes pattern (grey shaded, low pass Butterworth filtered with the 10-yr cut-off period) and step changes in anomalies (solid black line) detected by sequential t-test analysis of regime shift (STARS) of major ten species in Korean commercial catch. 


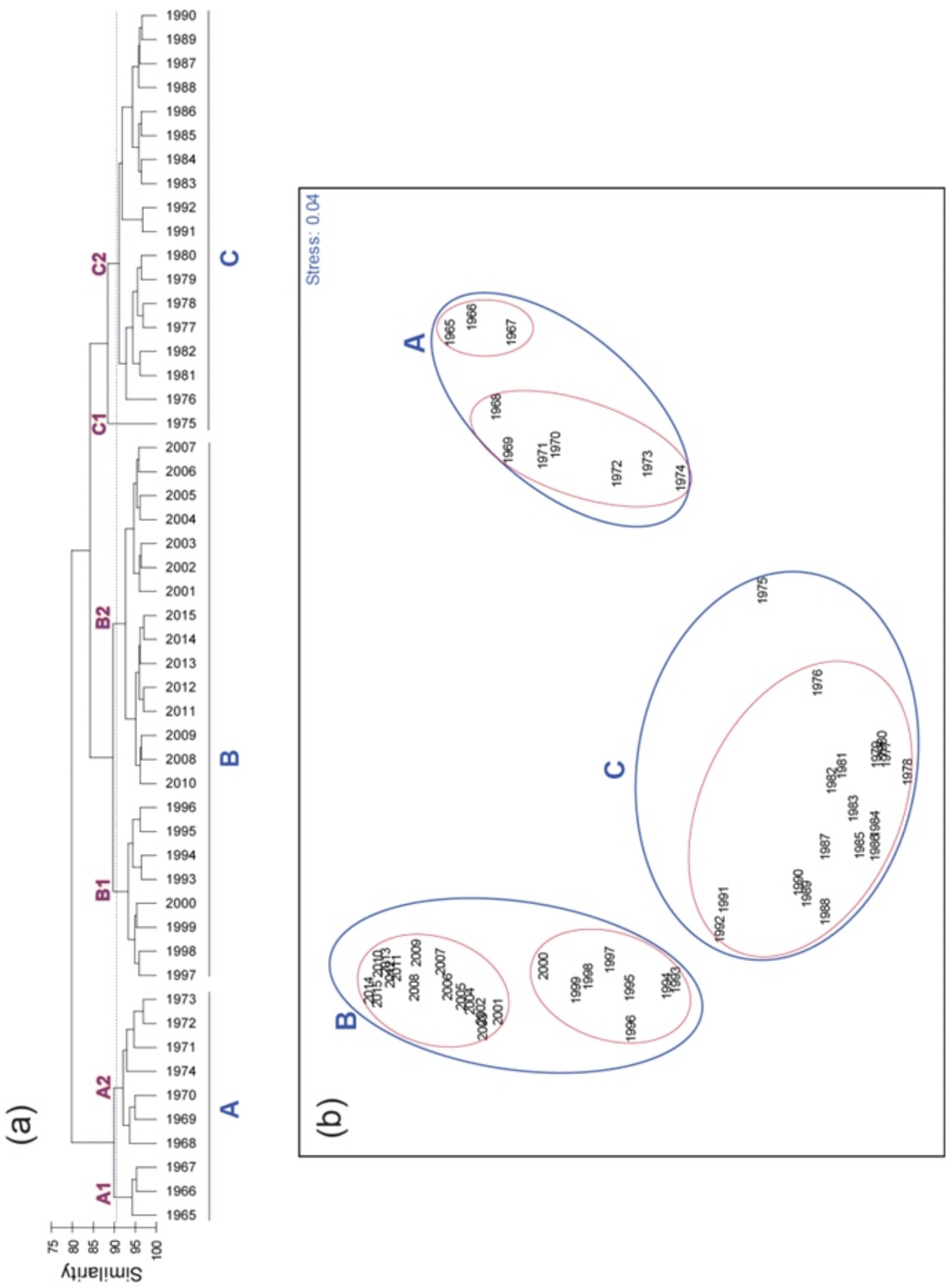

Fig. 6 : Comparison of fish assemblages from 1975 to 2015 using (a) hierarchical cluster and (b) non-metric multidimensional scaling ordination (nMDS) analyses based on Bray-Curtis similarity. 


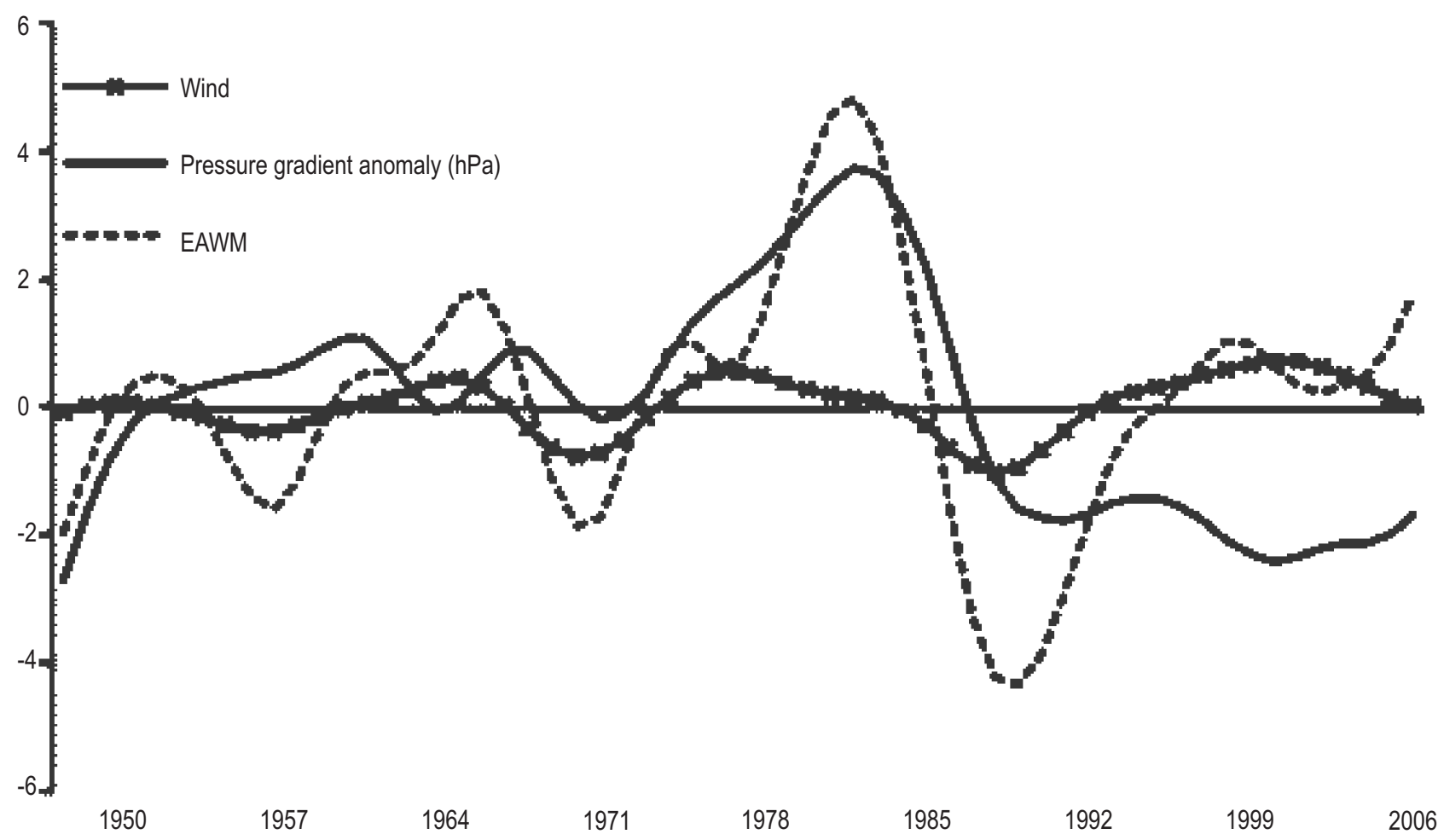

Fig. 7 : Time series of zonal wind of south East/Japan Sea $\left(35^{\circ}-38^{\circ} \mathrm{N} ; 130^{\circ}-133^{\circ} \mathrm{E}\right)$, pressure gradient between SHP-NPI and EAWM (smoothed by a low-pass Butterworth filter with 10-yr cut-off period). SHP: Siberian High Pressure, NPI: North Pacific Index, EAWM: EastAsian Winter Monsoon.

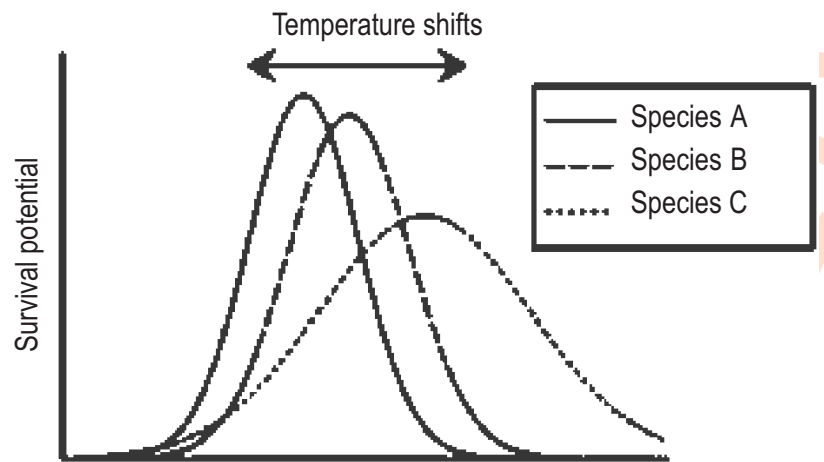

Temperature

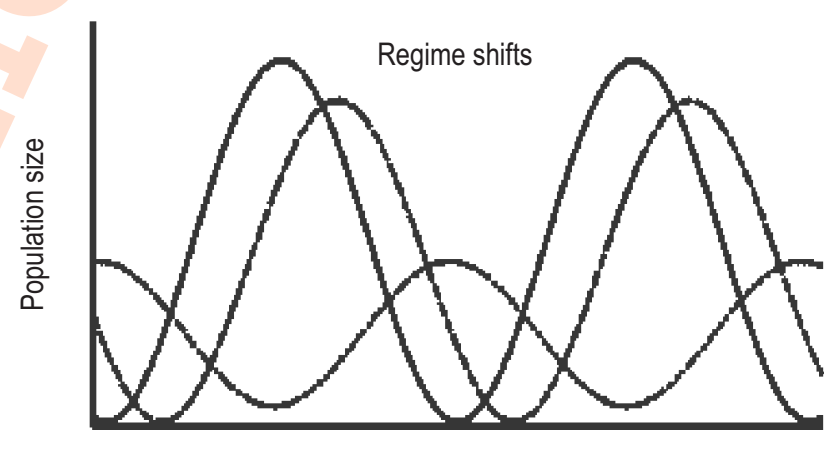

Multi-decadal time series

Fig. 8 : Conceptual framework of multi-species regime shifts of fish and plankton based on differential temperature optima and limits. Temperature shifts between differential optima (upper) could lead to different patterns of population dynamics (below) (Takasuka et al., 2007; Drinkwater et al., 2010).

Sea water temperature is one of the most important factors influencing fish population abundance directly by regulating their reproduction, phenology, recruitment and mortality. It has strong link with geographic distribution and migration pattern of any marine species (Morley et al., 2018). In Japanese waters, species-specific growth temperature optima were detected for Japanese anchovy (Engraulis japonicus) at $22^{\circ} \mathrm{C}$ and sardine (Sardinops melanostictus) at $16^{\circ} \mathrm{C}$ (Takasuka et al., 2007). So, differential preference and limits for growth, spawning or distribution exhibit sardine dominated cold regime and anchovies dominated warm regime in that waters (Fig. 8, Drinkwater et al., 2010). Synchronous pattern among climate indices in north Pacific region, SWT and major fish species in East Asian Marginal Sea regions are illustrated in Fig. 9. Walleye pollock which is a cold water species had positive shift in 1973 might be related to lower temperature at north East / Japan sea (1962-1975). Also 1975 negative shifts of sea water temperature at south East/Japan Sea had a positive influence on higher abundance of this species. A regime shift within Eastern Bering Sea in 1977 also favored survival of walleye pollock juvenile 


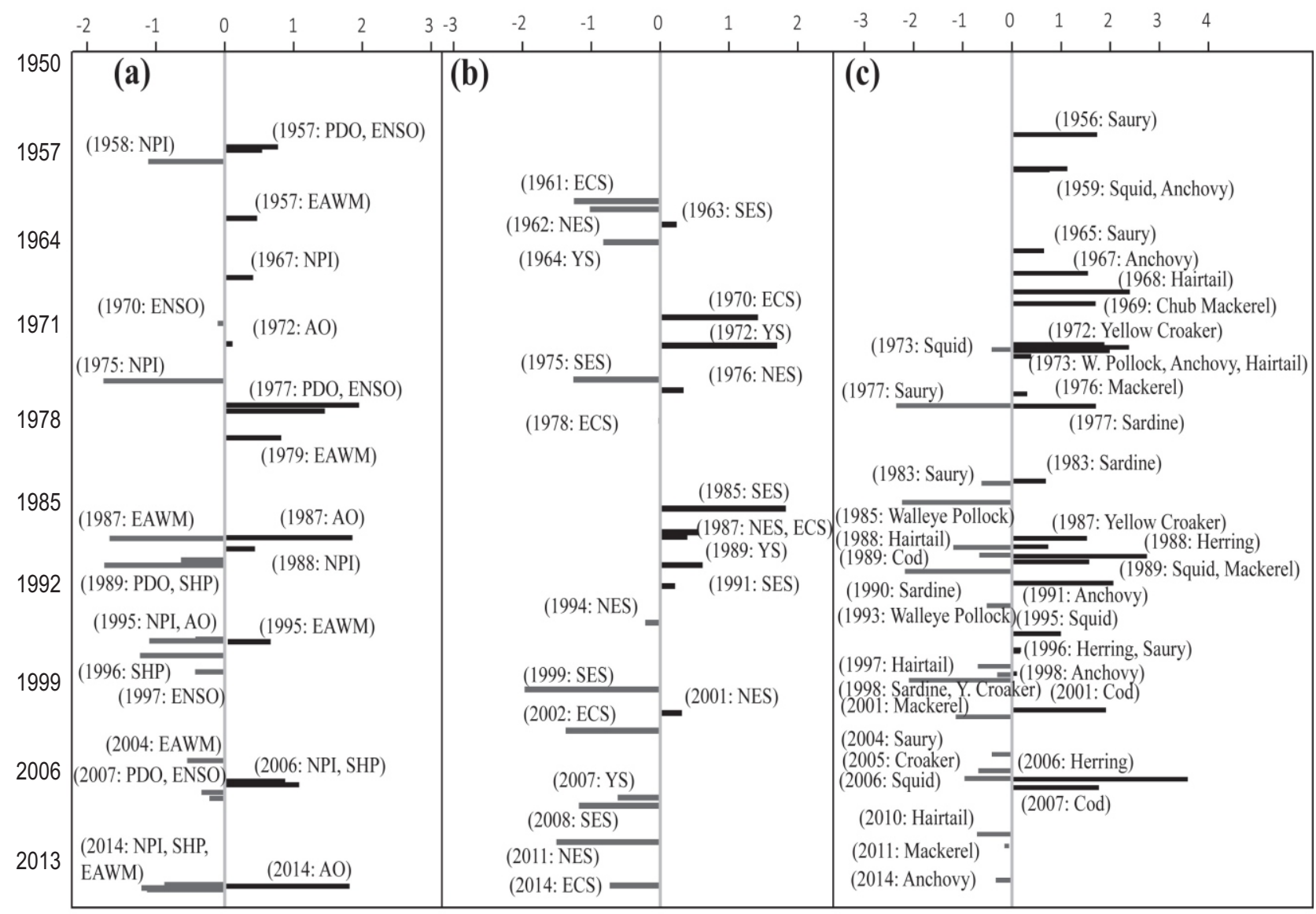

Fig. 9 : Regime shifts in climate indices (a), sea water temperature at $50 \mathrm{~m}$ depth (b), and major fisheries catch (c) since 1950s.

(Duffy-Anderson et al., 2016).Collapse of this fishery around mid 1980's might have influenced positive shifts of sea water temperature in north East/Japan Sea $(100 \mathrm{~m})$ and south East/Japan Sea $(50 \mathrm{~m}, 100 \mathrm{~m})$. Sea water temperature might have influenced early life cycle of this species. When walleye pollock spawn in upper layer of water column, the eggs float on the surface due to buoyancy. The increased sea water temperature in upper layer seems to unsuitable for hatching and survival of young walleye pollock because eggs and early life stage showed sensitively to oceanic conditions.

Positive shifts of common squid in 1989 might be related to positive shifts of sea water temperature in south East/Japan Sea in 1987 (10 m) and a positive shift in the north East / Japan Sea-East China Sea in 1987. Also negative shift in 2006 might be related to negative shift of sea water temperature in south East / Japan Sea after 1998 CRS and in East China Sea in 2002.

Japanese sardine prefer cold regime and very closely followed 1976 and 1988 climate regime shift for their enhancement and collapse pattern, respectively. Zhang et al.
(2000) mentioned that a higher abundance of Japanese sardine after 1976 CRS was reflected in an increased intensity of autumn blooms. Pacific saury got a negative shift and collapsed just after 1976 CRS might be closely influenced from negative shift of sea water temperature in south East/Japan Sea. However, Zhang et al. (2000) reported a temporal mismatch between the onset of spring primary productivity and feeding migration of Pacific saury for the collapse of this species. Asharp increase in TWC after 1976 CRS was reported, which in turn delayed the onset of primary productivity in spring and increased the intensity of autumn blooms in EJS. Japanese anchovy is closely related with 1988 climate regime shift when there was a positive shift of sea water temperature in East China Sea and in south East/Japan Sea. Abundance of Pacific cod (collapse after 1988 CRS and enhance after $1998 \mathrm{CRS}$ ) was correlated with warmer regime (after 1988 CRS) and colder regime (after 1998 CRS) in south East/Japan Sea. Chub mackerel population was enhanced just after 1988 CRS as sea water temperature of south East/Japan Sea and East China Sea were shifted to warmer regime and collapsed after 1998 CRS as both the regions were shifted to colder regime. Pacific herring in south East/Japan Sea region 
enhanced just after 1988 CRS; however it was shifted to its highest abundance in 2006 though this time was colder regime in EAMS. Abundance of hairtail was increasing from early 1970s and after 1976 CRS, population was at peak when East China Sea $(50 \mathrm{~m}$ and $100 \mathrm{~m})$ and Yellow Sea $(20 \mathrm{~m})$ were in colder regime period. This specie collapsed just after 1988 CRS when warmer regime prevailed. Yellow croaker followed the 1988 and 1998 CRS in Yellow Sea $(20 \mathrm{~m})$ for their enhancement and collapse pattern, respectively.

In conclusion, during 1976 regime shift, climate indices were shifted separately for long period; abrupt shift pattern in Pacific decadal oscillation, north Pacific index, and El Niño Southern Oscillation played a major role, earlier positive shifts were detected in most regions sea water temperature. In contrast, 1988 regime shift was occurred most abruptly and sudden shifts were detected in Arctic oscillation, Siberian high pressure and East Asian winter monsoon; all region sea water temperatures were positively shifted. Most of the climate patterns were shifted earlier in 1998 regime shift; sea water temperature of south East/Japan Sea and East China Sea were shifted abruptly in this period.

\section{Acknowledgments}

This research was a part of Basic Science Research Program through the National Research Foundation of Korea (NRF) funded by the Ministry of Education (2016R1A6A1A0501 1910) and the project titled 'Walleye Pollock stock management based on Marine Information \& Communication Technology', funded by the Ministry of Oceans and Fisheries, Korea.

\section{References}

Baik,C.I., C.I. Lee, K.H. Choi, and D.S. Kim: Variation of fisheries conditions of fishing ground of yellow croaker (Pseudosciaenapolyactis Bleeker) in the East China Sea and the Yellow Sea. J. Korean Fish Soc., 38, 413-424 (2005).

Beamish, R.J., J.R. King and G.A. McFarlane: Impacts of climate and climate change on the key species in the fisheries in the north Pacific in PICES working group on Climate Change, Shifts in Fish Production and Fisheries Management, PICES Scientific Report No. 35 (2008).

Beamish, R.J., G.A. McFarlane and J.R. King: Fisheries climatology: understanding decadal scale processes that naturally regulate British Columbia fish populations. In: Fisheries Oceanography: An integrative approach tofisheries ecology and management (Eds.: P.J. Harrison and T.R. Parsons). Blackwell Science, Oxford, pp. 94-145 (2000)

Beamish, R.J., C.E. Neville and A.J. Cass: Production of Fraser River sockeye salmon (Oncorhynchus nerka) in relation to decadalscale changes in the climate and the ocean.Can. J. Fish. Aquat. Sci., 54, 543-554 (1997).

Choi, Y.M., J.B. Lee, C.I. Zhang, C.I. Baik and J.H. Park:Assessment and management of common mackerel (Scomber japonicus) in Korean waters based on the relationship between recruitment and the ocean environmental factors. In: Abstracts of Korea-Japan
Joint GLOBEC Symposium: Long-term variation in the north western Pacific Ecosystems (Joint GLOBEC symposium, 23-25 August 2000) Busan, Korea, $52 \mathrm{p}(2000)$.

Choo, H.S. and D.S. Kim: The effect of variations in the Tsushima warm currents on the egg and larval transport of anchovy in the southern Sea of Korea. J. Korean Fish Soc., 31, 226-224 (1998).

Chiba, S., Y. Hirota, S. Hasegawa and T. Saino: North-south contrast in decadal scale variations in lower trophic ecosystems in the Japan Sea. Fish Oceanogr., 14, 401-412 (2005).

Chung, S.D., S. Kim and S. Kang: Ecological relationship between environmental factors and Pacific cod (Gadus macrocephalus) catch in the southern East/Japan Sea. Ani. Cell. Syst., 17, 374-382 (2013).

Clarke, K.R. and R.N. Gorley: PRIMER version 6 user manual/tutorial. PRIMER-E, Plymouth, UK (2006).

Drinkwater, K.F., G. Beaugrand, M. Kaeriyama, S. Kim, G. Ottersen, I. Perry, H.O. Pörtner, J.J. Polovinai and A. Takasukaj: On the processes linking climate to ecosystem changes. J. Mar. Syst., 79, 374-388 (2010).

Duffy-Anderson, J.T., S.J. Barbeaux, E.V. Farley, R. Heintz, J.K. Horne, S.J. Parker-Stetter, C. Petrikd, E.C. Siddon and T.I. Smart: The critical first year of life of walleye pollock (Gadus chalcogrammus) in the eastern Bering Sea: Implications for recruitment and future research. Deep Sea Res. Part 2 Top. Stud. Oceanogr., 134, 283-301 (2016).

Gordon, A.L. and C.F. Giulivi:Pacific decadal oscillation and sea level in the East/Japan Sea. Deep Sea Res. Part 1 Oceanogr. Res. Pap., 51,653-663(2004).

Gong, D.Y. and C.H. Ho: The Siberian high and climate change over middle to high latitude Asia. Theo. Appl. Climatol., 72, 1-9 (2002).

Gong, Y., H.D. Jeong, Y.S. Suh, J.W. Park, K.T. Seong, S.W. Kim, K.H. Choi and I.S. Han: Fluctuations of pelagic fish populations in relation to climate shifts in the Far-East regions. J. Ecol. Biol.,30, 23-38 (2007).

Gong, Y. and Y.S. Suh: Effect of climate-ocean changes on the abundance of Pacific saury. J. Environ. Biol., 34, 23-30 (2013).

Jung, H.K., S.M.M. Rahman, C.K. Kang, S.Y. Park, S.H. Lee, H.J. Park, H.W. Kim and C.I. Lee: The influence of climate regime shifts on the marine environment and ecosystems in the East Asian Marginal Seas and their mechanisms. Deep Sea Res. Part 2 Top. Stud. Oceanogr., 143, 110-120 (2017).

Jung, S., Y.S. Kang, Y.S. Suh, J.Y. Yang and J. Kim: Spatial variability in oceanographic conditions of sea waters off Korea in relation to the regional climate changes during the past 40 years. In: International Council for the exploration of the sea, Annual Science Conference, Helsinki(2007).

Jhun, J.G. and E.J. Lee: A new East Asian winter monsoon index and associated characteristics of the winter monsoon. J. Clim., 17, 711-726 (2004).

Kang, S., S. Kim and S.W. Bae: Changes in ecosystem components induced by climate variability off the eastern coast of the Korean Peninsula during 1960-1990. Prog. Oceanogr., 47, 205-222 (2000).

Kang, Y.S., S. Jung, Y. Zuenku, I. Choi and N. Dolganova: Regional differences in the response of the mesozooplankton to oceanographic regime shifts in the northeast Asian marginal seas. Prog. Oceanogr., 97, 120-134(2012).

KFA(Korea Fisheries Association): Korean fisheries yearbook (2014). Kim, S., C.I. Zhang, J.Y. Kim, S. Kang and J.B. Lee: Country Reports, 
Republic of Korea, Impacts of Climate and Climate Change on the Key Species in the Fisheries in the North Pacific. PICES Scientific Report35, pp. 101-135 (2008).

Kim, J.Y., Y.S. Kang, H.J. Oh, Y.S. Suh and J.D. Hwang: Spatial distribution of early life stages of Japanese anchovy (Engraulis japonicus) and hairtail (Trichiurus lepturus) and their relationship with oceanographic features of the East China Sea during the 1997-1998 El Nino event. Estuar. Coast. Shelf Sci., 63, 13-21 (2005).

Kim, J.Y.: Relationship between anchovy, Engraulis japonica, egg and larval density and environmental factors in the eastern waters of Korea. Bull. Korean Fish Soc., 25, 495-500 (1992).

Kim, S., C.I. Zhang, J.Y. Kim, J.H. Oh, S. Kang and J.B. Lee: Climate variability and its effects on major fisheries in Korea. Ocean Sci. J., 42, 179-192(2007).

Kim, Y.H., Y.J. Kang, S.H. Choi, C.S. Park and C.I. Baik: Population analysis by the reproductive ecological method for common squid, Todarodespacificus in Korean Waters. Bull. Korean Fish. Soc., 30, 523-527 (1997).

Lee, C.I., J.Y. Lee, K.H. Choi and S.E. Park: Long-term trends in pelagic environments of the East Sea ecosystem. Ocean Sci. J., 43, 1-7 (2008).

Lee, Y. and D.Y. Kim: Measuring surface water temperature effects on the walleye pollock fishery production using a translogcost function approach. Environ. Resour. Econ. Rev., 19, 897-916 (2010).

Limsakul, A., T. Saino, T. Midorikawa and J.I. Goes: Temporal variations in lower trophic level biological environments in the northwestern North Pacific subtropical gyre from 1950 to 1997. Prog. Oceanogr., 49, 129-149 (2001).

Miller, A.J., F. Chai, S. Chiba, J.R. Moisan and D.J. Neilson: Decadalscale climate and ecosystem interactions in the North Pacific Ocean.J. Oceanogr., 60, 163-188(2004).

Mantua, N.J., S.R. Hare, Y. Zhang, J.M. Wallace and R.C. Francis: A Pacific interdecadal climate oscillation with impacts on salmon production. Bull. Amer. Meteor. Soc., 78,1069-1079 (1997).

Morley, J.W., R.L. Selden, R.J. Latour, T.L. Fro Ėlicher, R.L. Seagraves and M.L. Pinsky: Projecting shifts in thermal habitat for 686 specieson the North American continental shelf. PLoS One,13, e0196127 (2018).

Park, J.H., C.H. Choi and J.H. Lee: The relationship between coastal cold water and catch conditions of common squid (Todarodes pacificus Steenstrup) in the east sea of Korea in summer. Bull. Korean Soc. Fish. Technol., 34, 105-116 (1998).

Rahman, S.M.M. and C.I. Lee: Long term changes pattern in Marine Ecosystem of Korean waters. J. Korean Soc. Mar. Environ. Saf., 18, 193-198 (2012).
Rebstock, G.A. and Y.S. Kang: A comparison of three marine ecosystems surrounding the Korean peninsula: Responses to climate change. Prog. Oceanogr., 59, 357-379 (2003).

Rodionov, S.N.: A sequential algorithm for testing climate regime shifts. Geophys. Res. Lett., 31, L092024 (2004).

Sakurai, Y., H. Kiyofuji, S. Saitoh, T. Goto and Y. Hiyama: Changes in inferred spawning areas of Todarodes pacificus (Cephalopoda: Ommastrephidae) due to changing environmental conditions. ICES J. Mar. Sci., 57, 24-30 (2000).

Takasuka. A., Y. Oozeki and I. Aoki: Optimal growth temperature hypothesis: Why do anchovy flourish and sardine collapse or vice versa under the same ocean regime? Can. J. Fish. Aquat. Sci., 64, 768-776 (2007).

Tian, Y., Y. Uen, M. Suda and T. Akamine: Decadal variability in the abundance of Pacific saury and its response to climatic/oceanic regime shifts in the north western subtropical Pacific during the later half century. J. Mar. Syst., 54, 234-259 (2004).

Tian, Y., H. Kidokoro and T. Watanabe: Long-term changes in the fish community structure from the Tsushima warm current region of the Japan/East Sea with an emphasis on the impacts of fishing and climate regime shift over the last four decades. Prog. Oceanogr., 68, 217-237 (2006).

Thomson, D.W.J. and J.M. Wallace: The Arctic Oscillation signature in the winter time geo-potential height and temperature fields. Geophys. Res. Lett., 25, 1297-1300 (1998).

Trenberth, K.E. and J.W. Hurrell: Decadal atmosphere-ocean variations in the Pacific. Clim. Dyn., 9, 303-319 (1994).

Yatsu, A., S. Chiba, Y. Yamanaka, S.I. Ito, Y. Shimizu, M. Kaeriyama and Y. Watanabe: Climate forcing and the Kuroshio/Oyashio ecosystem. ICES J. Mar. Sci., 70, 922-933 (2013).

Yatsu, A., T. Watanabe, M. Ishida, H. Sugisaki and L.D. Jacobson: Environmental effects on recruitment and productivity of Japanese sardine Sardinops melanostictus and chub mackerel Scomber japonicus with recommendations for management. Fish Oceanogr., 14, 263-278 (2005).

Yeh, S.W., Y.G. Park, H.S. Min, C.H. Kim and J.H. Lee: Analysis of characteristics in thesea surface temperature variability in the East/Japan Sea. Prog. Oceanogr., 85, 213-223 (2010).

Zhang, C.I., J.B. Lee, Y.I. Seo, S.C. Yoon and S. Kim: Variations in the abundance of fisheries resources and ecosystem structure in the East/Japan Sea. Prog. Oceanogr., 6, 1245-265 (2004).

Zhang, C.I., J.B. Lee, S. Kim and J.H. Oh: Climatic regime shifts and their impacts on marine ecosystem and fisheries resources in Korean waters. Prog. Oceanogr., 47, 171-190 (2000). 